\title{
Brainport: the power of cooperation creating the industries of the future
}

CARINA WEIJMA*

\begin{abstract}
Purpose of the paper: This case study offers information on Brainport region Eindhoven (Brainport) in the Netherlands by explaining the cooperation between companies, government and knowledge institutes.

Methodology: Focusing on the importance of the High Tech Systems \& Materials sector, including a strong Lifetec cluster. The presence of powerful major companies like ASML, DAF, Philips, Océ, DSM, NXP and VDL is unique, as is the related extensive network of hightech SMEs suppliers (the high tech open supply chain Brainport Industries) and an internationally renowned Design cluster.

Findings: Including graphs supporting the claim that Brainport is a top technology region of European and global status and the cornerstone of the Dutch economy.

Research Limits: The qualitative variables data collected are offered by EUROSTAT, $C B S$, and Dutch high tech companies. To avoid complexity for the reader, no other qualitative variables were included on Dutch national numbers.

Practical implication: The case study shows that the strongest asset of Brainport is cooperation among industrial champions, market and technology leaders (or the market and technology leaders?), sustained by the government. These form a winning team through cooperation, with new governance as its starting point. Companies and knowledge institutes cooperate to create and make the technology of tomorrow and to help make the Netherlands a safe and sustainable place to live and remain economically prosperous.

Originality of the paper: This case study is based on the knowledge of five years working in the Brainport region in various roles and on publications, research, interviews and stories of many business and governmental leaders in the Brainport region. The story offered in this case study should be seen as a wonderful joint effort between companies, government and knowledge institutes
\end{abstract}

Key words: Brainport; Open Innovation; Cooperation between government, companies and knowledge institutes

\footnotetext{
Strategic advisor of Brainport Industries and Brand Manager of the high tech sector of the Netherlands

e-mail carina.weijma@carwei.com
}

sinergie, rivista di studi e ricerche

n. 91, Maggio-Agosto 2013, pp. 3-20

ISSN 0393-5108 - DOI 10.7433/s91.2013.02 


\section{Brainport region Eindhoven, cornerstone of the Dutch economy}

Brainport (Brainport region Eindhoven, fig. 1) is a fitting name for a region bursting at the seams with innovation. This is the Southeast Netherlands; at its heart lies Eindhoven. Brainport region Eindhoven is close to Paris in France (450 km) and London in Great Britain $(460 \mathrm{~km})$. As a basis for added value the region exploits knowledge and technology. Brainport also has close connections across country borders with Leuven in Belgium (100km) and Aachen in Germany (100 km).

Fig. 1 Brainport stands for progress, top technology, innovation, success, cooperation, region, ecosystem, international network

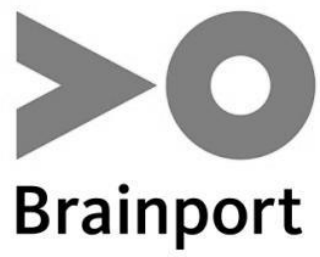

Fig. 2: Where is Brainport

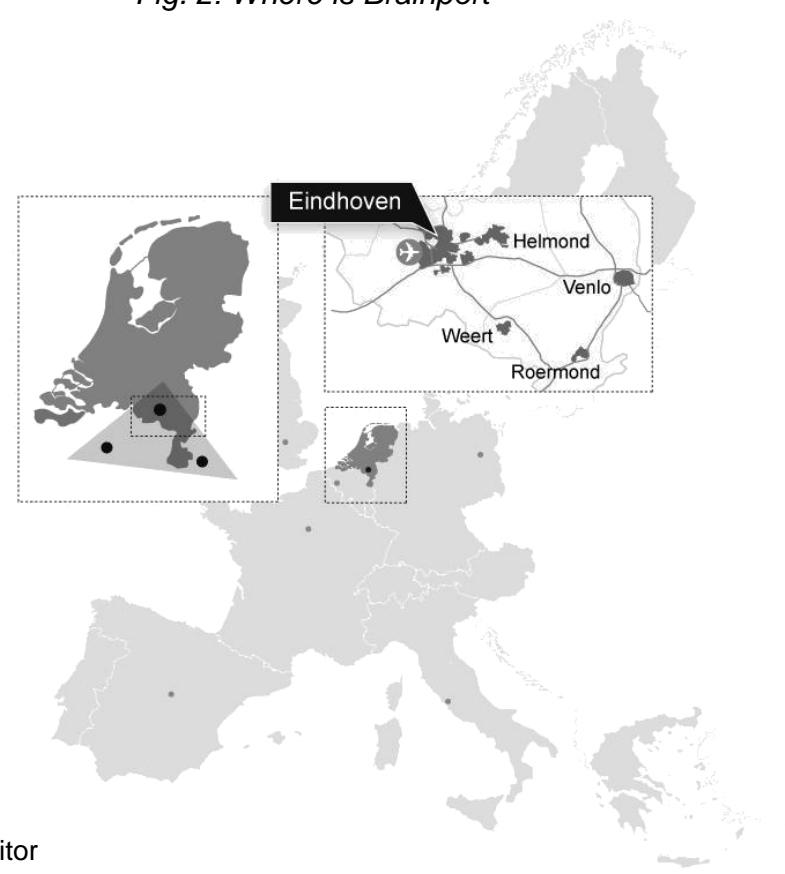

Source: Brainport Monitor 
Brainport is a European top technology region of stature. There's a long tradition of technical ingenuity in Brainport; it never fails to surprise. Take, for example, classic inventions and applications such as the first overseas radio broadcast, the video phone, electronic music and the $\mathrm{CD}$. And there are more recent examples, such as the LED lamp, Blu-Ray Disc, the world's leading manufacturing systems for computer chips, the MRI scanner, innovative transport systems and the nanomicroscope for pupils in secondary education.

The Southeast Netherlands contributes significantly to the rest of the Netherlands, with $35 \%$ of all Dutch exports coming from this region. Together with the mainports of Amsterdam and Rotterdam, the Southeast Netherlands is the bulwark of the Dutch economy. The very strong performance of the Southeast Netherlands can be attributed to the investments made by companies in research and development (R\&D) into new products, services and technologies. Nearly half of all $\mathrm{R} \& \mathrm{D}$ investments within our national borders is spent here. And more than half of all patents come from the Southeast Netherlands, part of the cross-border top technology region of Eindhoven-Leuven-Aachen (TTR ELAt). The economy of the Southeast Netherlands acts on a European level in various partnerships and in the top technology region of Eindhoven-Leuven-Aachen. This is a region of approximately 9.3 million residents, with an economy that is larger than that of Finland with more R\&D investment than Singapore. It makes the Southeast Netherlands one of Europe's strongest innovation regions.

An example of European cooperation is Holst Centre, a partnership between Imec Leuven in Belgium and TNO in the Netherlands. Two co-locations of 'Knowledge Innovation Communities' (KICs) of the European Institute of Innovation and Technology are also accommodated in the Southeast Netherlands: the KIC InnoEnergy and the KIC ICT. Furthermore in the Southeast Netherlands, Chemelot Campus, RWTH and RWTH Aachen Campus are exploring the possibility of forming a consortium in Europe to make use of their complementarity and to boost efficiency.

Brainport's residents include universities, various renowned knowledge and research institutes, and hundreds of innovative companies both large and small SME's [SMEs stands for small and medium sized enterprises]. Philips, DAF, ASML, VDL, TomTom and FEI are among the well-known 'major players' established here, along with Original Equipment Manufacturers (OEM's) and companies in the high tech supply chain. Many people are working to invent, develop, design, produce and sell innovative products and technologies in a climate of open innovation. Here, top scientists, designers, producers and marketers are doing complementary work: creating the industries of the future.

A survey of entrepreneurship in Brainport region Eindhoven has shown that more and newer, entrepreneurs are establishing themselves in this region than in the rest of the Netherlands. The number of people just starting up or in the starting phase of a company is relatively high. The attitude among the population towards entrepreneurship is also more positive than the national average. 
The top technology region is capable of earning money. Research shows that all over the world it is especially private $R \& D$ investments that are a booster for economic growth. This is proven by the development of Brainport region Eindhoven. In this region clusters of SMEs and multinationals that perform above average are located, also in a European context.

A requirement for innovations and economic success is a well educated labour force. Brainport stimulates a qualitatively effective range of education and a knowledge infrastructure with close ties to the industry. The region has three strong universities with different but complementary profiles in Tilburg, Eindhoven and Maastricht: alpha, bèta and gamma, a university medical centre, and the open university. Next to these are the good and broad higher educational establishments Fontys Hogescholen, Hogeschool Zuyd, the world-leading Design Academy in the field of industrial design and the renowned Hogeschool HAS Den Bosch in the field of Agrofood. At all educational levels (from secondary to university) educational establishments work together with industry. However, in a quantitative sense, compared with the national average, the public knowledge infrastructure is not up to par.

\section{Eindhoven region, from past to present}

The current Brainport way of working and cooperating has been built on a history of economic problems that prompted their solutions. There is an important historical reason for a cooperating attitude in Southeast Netherlands, the Brainport region Eindhoven. At the end of the last Ice Age, around 10,000 years ago, the North Sea was a large lowland plain. As the temperature increased, the sea level rose and after a few thousand years, the North Sea was on the doorstep of what we now call the Netherlands. The grounds in Southeast Netherlands were sandy with no fertile soil. People living in this area had to work together to survive. This explains the cooperative attitude in the Southeast of the Netherlands. The cooperation of the Rabobank for example is based on the idea that all contributors are owners.

Numbers of export from the Brainport region were always higher than the total for the Netherlands. However, compared to the rest of the Netherlands the economy of Brabant is rather sensitive due to its historically developed economic structure: two big companies, DAF and Philips, offered the main jobs in the '90s. And the manufacturing industry, with $23 \%$ employment, is relatively large in Brabant as compared to the Netherlands as a whole (18\%). However, it is way below the $29 \%$ for the EU27 as a whole. The economy of Brabant was hit harder than the rest of the Netherlands by the dotcom crisis and recently by the credit-crunch crisis, but it also recovered more speedily. The level and trend for GDP per capita here is above the EU average, but similar to the national average.

After the last downturn in the '90s, government and companies decided to do their utmost to prevent companies and employees in Eindhoven from a repetition of 
this disaster. This decision paved the way for stronger cooperation between government and companies.

Besides the appreciation of cooperation between companies and dedicated public research institutes in innovation projects, the region has also recently experienced another type of beneficial impact from cooperation between the public and private sides of the research sector. In 2009, the region initiated a scheme to remedy the impact of the crisis which threatened many research positions in the region. With a national support measure researchers from the companies in the region were temporarily stationed at TNO or the university. This has proved to have been a good instrument, as most researchers have returned to their old positions.

Fig. 3: Export development Brainport versus the Netherlands

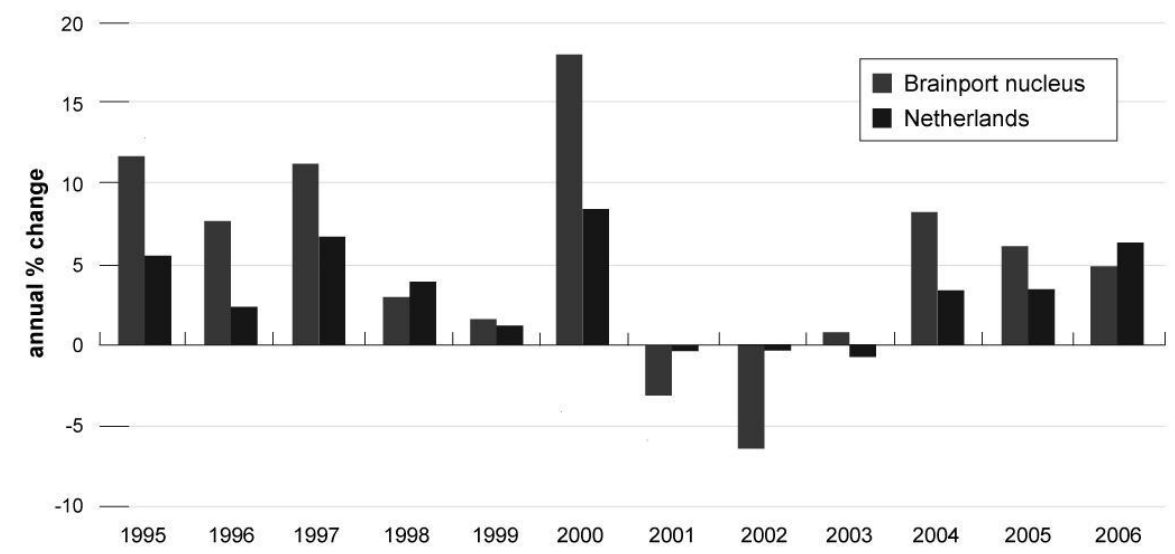

Source: ERBO

\section{From closed to open innovation}

The crises at Philips and DAF lead to a new approach regarding innovation. Philips' laboratories and offices were built on an industrial park with big fences around it. The increasing availability and mobility of skilled workers, the growth of the venture capital market, external options for ideas sitting on the shelf, and the increasing capability of external suppliers, paved the way to open innovation. See fig. 4.

In an open innovation model companies cooperate with each other and with internationally active knowledge institutes like universities, university medical centres and hospitals. In Brainport for example TNO and the Dutch Polymer Institute cooperate by sharing and multiplying knowledge in an open environment before they bring their products to the market. Open innovation is almost always multidisciplinary; bèta programmes work with market researchers, sociologists and 
psychologists. Meeting facilities and accessible research facilities are key criteria. Innovation programmes like Point One (focused on high-tech systems), HTAS (specifically geared to automotive), CTMM (Centre for Translational Molecular Medicine) and BMM (Biomedical Materials) also play an important role.

An innovation campus with international allure is the High Tech Campus Eindhoven. This innovation campus is built on the strong foundation of the top players in High Tech Systems \& Materials. The High Tech Campus Eindhoven (founded in 1998) is synonymous with open innovation. In an area of just one square kilometer in Eindhoven, more than 8,000 researchers, developers and entrepreneurs work closely together developing the technologies and products of tomorrow. Philips established the High Tech Campus to act as a single location for all its national R\&D activities. This approach proved highly successful. The atmosphere of openness and the concentration of high-end knowledge and facilities produced considerable interaction between the researchers. Knowledge sharing and mutual inspiration generated a definite boost for the innovative capacity of the organization. To further accelerate this process, Philips decided to open up the Campus to other technological companies in 2003. The result was massive growth. The atmosphere changed from Pure Research to Product Research, to Open innovation. The campus now has unique research facilities and forms a hotspot for innovation.

Fig. 4:Corporate R\&D and Open Innovation

Pure Corporate R\&D evolved from an internal supply function to 'open innovation'

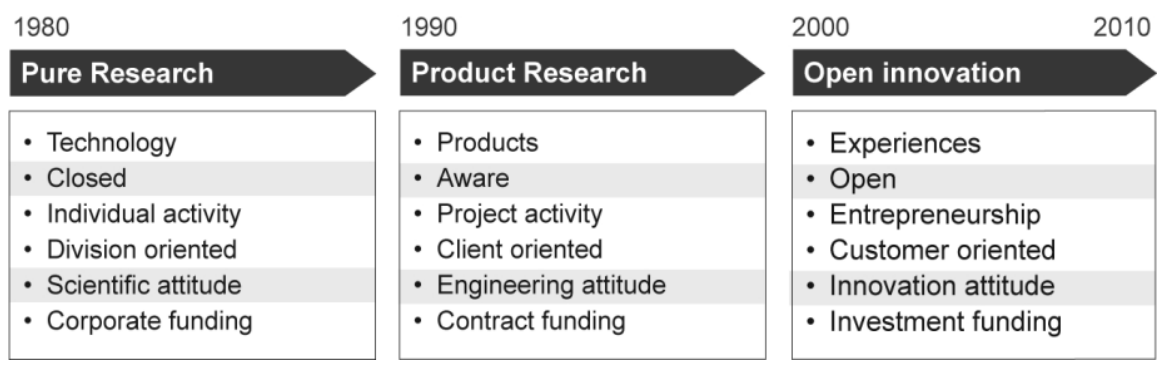

Source: Brainport Development NV, (2010), Brainport Monitor, Eindhoven

\section{Brainport Development Organization - new governance model}

The Eindhoven region has a unique tradition of partnership between industry, knowledge institutions, and the government that drives the region forward. Created in the crisis period of the ' 90 s and embedded in the Brainport Development organization, founded in 2006. A new style development agency in which representatives from the industry, research and the government work side by side to strengthen Brainport region Eindhoven. It is a horizontal Triple Helix collaboration, since companies and SMEs, knowledge institutes and governments collaborate at 
various and multiple levels. The project management approach consists of a large number of bottom-up initiatives with external project owners. Brainport Development asks one of the involved firms or knowledge institutes to take ownership of an initiative or project.

As a result, Brainport Development stimulates and develops regional and (inter)national projects and programmes, promotes Brainport region Eindhoven at home and abroad, facilitates regional industry through vehicles like business advice and funding, start-up provisions, business accommodation and business centres, and monitors regional trends. Strategy and activities are clustered around four domains: People, Technology, Business and Basics. (Basics: compared with the national picture, the quality of living and liveability in Brainport region Eindhoven is above average).

All activities focus on innovative projects in the major industries: High-Tech Systems \& Materials, Food, Automotive, Life Tec (medical technology) and Design. The aim is to expand Brainport's international competitive position as a hotspot in the field of innovations. By spurring on innovative projects they are helping to build the region's already strong economy. And as a promoter of the Brainport region Eindhoven they are working - internationally - to create an image that truly reflects all that Brainport has to offer.

Finally, when it comes to Governance there are several organizations that have an umbrella function and play a coordinating role in the direction of a cluster. Examples of these cluster management organizations are the Design Cooperation Brainport, Automotive Technology Campus and the high tech open supply chain Brainport Industries.

The new governance model is based on the following principles:

- trust: in networking, leadership, and bottom up instead of top down;

- leadership: in a triple helix cooperation between companies, educational knowledge institutes and government;

- scale: not limited by the boundaries of a public administration, based on a functional network, thinking global and acting local;

- focus: on clustering, competences, resources, and partners, in an integrated program.

\section{Ecosystem and domains}

In the Brainport region as well as the way of working of Brainport Development, the entire ecosystem is divided into five domains: People, Technology, Business, Basics and Governance. The facilities for this case study are categorized and described according to this structure. When it comes to people, knowledge institutes and the industry work together when attracting international knowledge workers. Having a sufficient amount of high skilled employees in the labor force is a critical success factor for Brainport. When it comes to Technology, the research facilities and programmes that can be regarded as standard shared facilities are described. In 
the Business domain, supporting facilities are for example the business incubation concept that aims to increase the number of start-ups and provides several (physical) supporting facilities. Furthermore, living labs/test beds present in the region allow organizations to test if their products are mature and ready for sale. Then, the Basics domain encompasses all the boundary conditions for a strong region. One of the aspects is whether a location is attractive for organizations and knowledge institutes with similar activities. In this situation, a top location enhances productivity and added value from companies and allows them to profit from present knowledge and skills.

\section{Spearhead sectors}

The five spearhead sectors - Automotive, Design, Food, High Tech Systems \& Materials and LifeTec - are worth $16.1 \%$ of the jobs in Southeast Netherlands. All five spearhead sectors are drivers for employment in other sectors and thus key cornerstones of the regional and national Dutch economy. The largest of these spearhead sectors is High Tech Systems \& Materials, which employs more than 40,000 people, equivalent to a good $10 \%$ of all the jobs in the region. A comparison with the national employment picture of these sectors reveals that these spearhead sectors are concentrated in Brainport region Eindhoven to a large extent. For instance, the proportion of jobs in Automotive, High Tech Systems \& Materials and LifeTec in the region is much greater than in the rest of the Netherlands. In 2011 the total number of people working within the five spearhead sectors rose by $8 \%$ compared to 2010 , way above the national average of $1 \%$.

Key players in these spearhead sectors in the South of the Netherlands are the campuses located around Eindhoven: the high tech campus Eindhoven, the Technical University campus (TU/e), the High Tech Automotive Campus in Helmond, and the so-called Design Campus around the Design Academy. A Food Technology Park is also being developed in Helmond, as well as plans for the Brainport Industries Park for high tech suppliers in Eindhoven. They function as supporting facilities for companies located in the region.

\section{Brainport facts and figures}

The private expenditure in R\&D in the Brainport region Eindhoven is higher than the public expenditure. The international operating companies responsible for the R\&D expenditure are ASML, FEI, Océ, Philips Healthcare and DAF. Market champions, worldwide operating: ASML: the world's leading provider of lithography systems for the semiconductor industry. FEI Company: premier provider of the highest resolution electron and ion-beam microscopes and tools for nanoscale applications across many industries like industrial and academic materials research, life sciences and semiconductors. Philips Healthcare: market leader in intelligent 
medical technology e.g. Imaging Systems, Home Healthcare Solutions, Clinical Care Systems, Healthcare Informatics. Océ: owned by Canon and one of the worlds largest suppliers of document management and printing for professionals. DAF: owned by the American PACCAR. DAF Trucks has large production facilities in Eindhoven, the Netherlands and in Westerlo in Belgium. Thanks to its high efficiency and world class manufacturing and products, the company has established a strong competitive position on the European market.

The very high innovation performance in terms of the number of EPO patents per million inhabitants is typical of the region. The research lab of Philips in Eindhoven is mainly responsible for this high number of patents, as well as for the high business R\&D expenditures.

Fig 5: R\&D spending in \% of GRP Southeast Brabant

\section{R\&D SPENDING}

$\%$ of GRP • Southeast Brabant

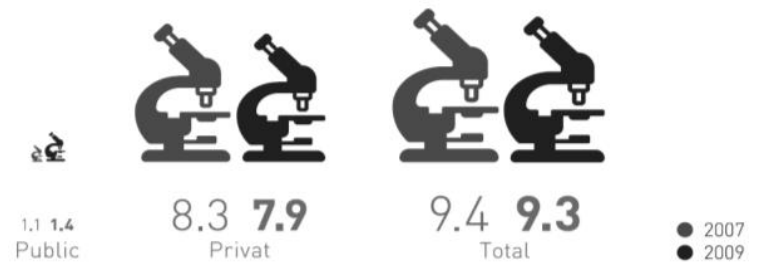

Source: Eurostat, CBS, Brainport Monitor, 2003; 2005; 2007; 2009

Fig 6: total R\&D expenditure (\% of GRP)

Total R\&D expenditure (\% of GRP)

* Statistics on Southeast-Brabant on private $R \& D$ lag one year behind

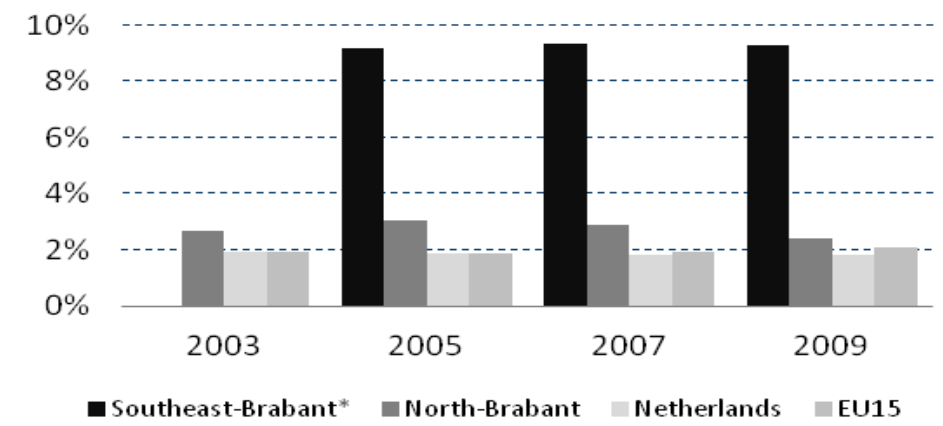

Source: Eurostat, CBS, Brainport Monitor 2007; 2009 
Fig. 7: EPO patents per million population (2002)

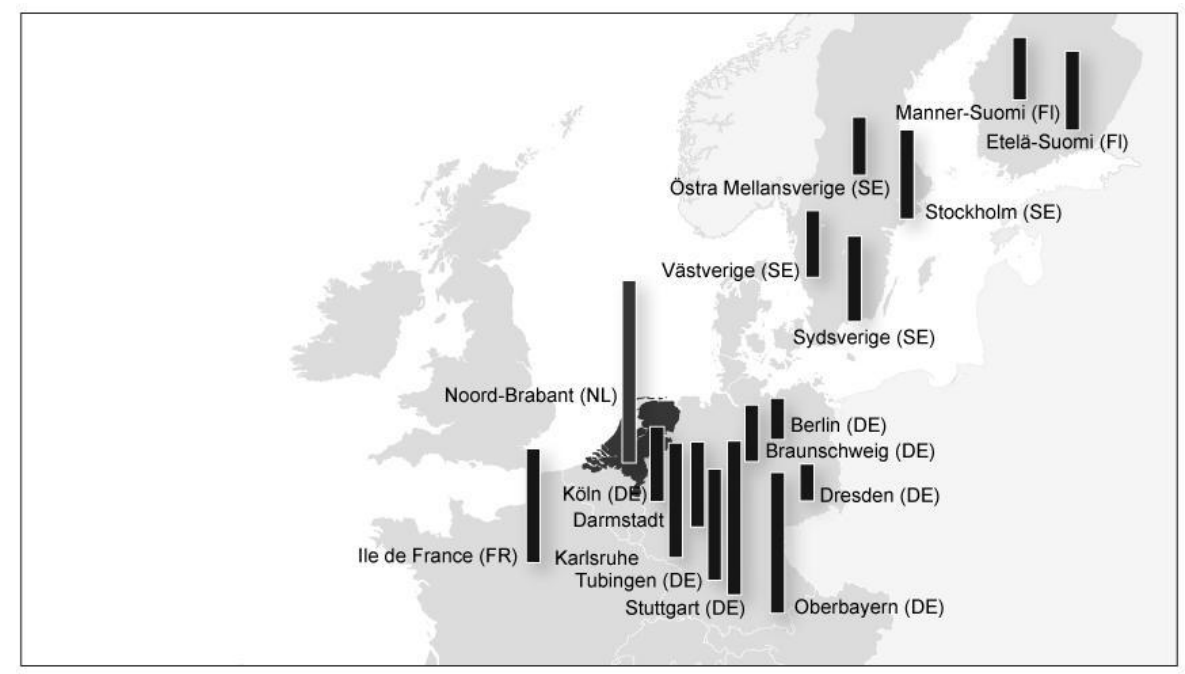

Source: Eurostat, 2002

Fig. 8: Number of patents per region

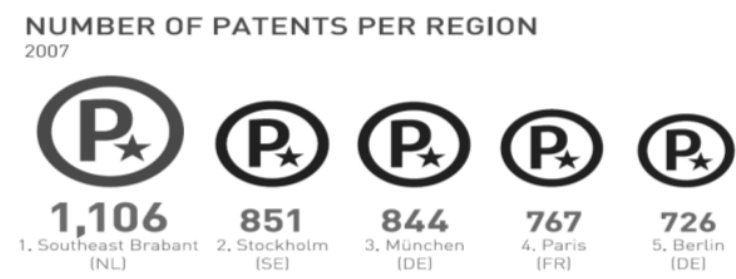

Source: Brainport Monitor

\section{World-class companies}

World-class, knowledge-intensive international companies in the Southeast Netherlands active in one of the top sectors (High Tech Systems \& Materials, Chemical Engineering \& Chemistry, and Agrofood) spend 3.3 billion euros each year on research and development (R\&D) and export products and services worth 80 billion euros). Among the leading world players that have a unique market position are ASML, Canon (Océ), DAF, DSM, FEI, NXP, Philips and VION, plus many smaller but equally excellent companies like Fuji, Annatech, Vanderlande Industries, Kverneland, Pamgene and CFS. The internationally competitive creative industry also plays a key role. 
Brainport is an innovative SME sector: about $26 \%$ of all companies in the Southeast Netherlands are innovative. Moreover, participation of small and mediumsized enterprises in national innovation schemes, innovation vouchers, innovation performance contracts and innovation programmes is above average: $44 \%$ of these specific national funds end up in the Southeast Netherlands.

The Southeast Netherlands has powerfully embedded chains of suppliers of services (like R\&D) and semi-finished products in manufacturing. Research and development, design, production and sales all occur within close proximity of each other, with $70 \%$ of the first-line suppliers of several major OEMs (Original Equipment Manufacturers) located within $40 \mathrm{~km}$ of Eindhoven. The same applies to second and third-line ancillary suppliers.

Fig.9: Technology leaders, market champions

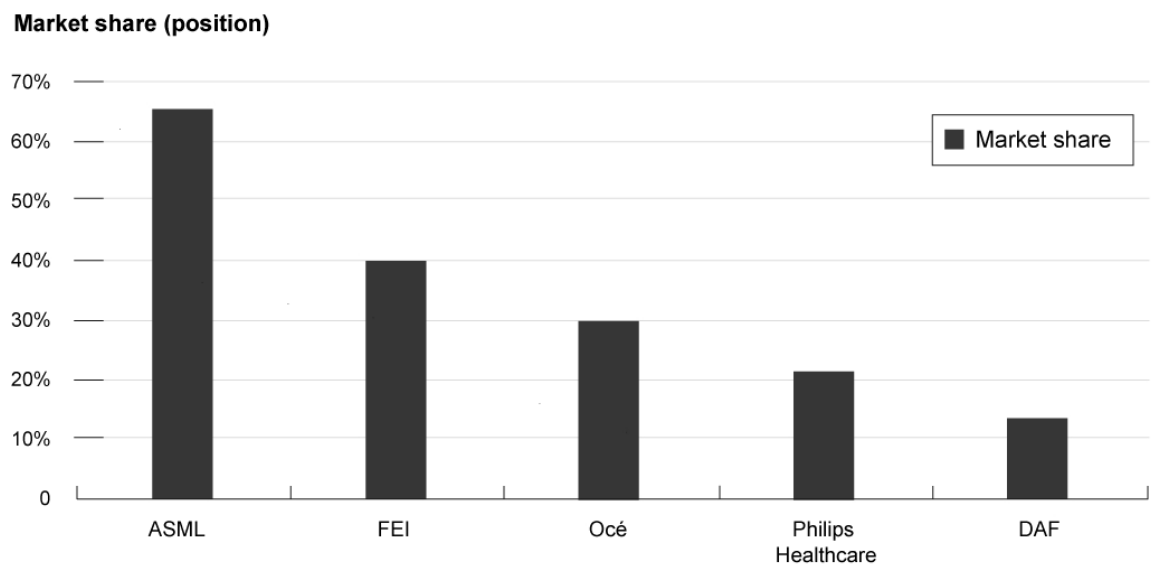

Source: ASML, FEI, OCe, Philips Healthcare, DAF, 2012

\section{Brainport Industries, the high tech open supply chain}

In 2011, many agencies published reports stating how important manufacturing is. In both the Netherlands and the US there is a call for more input into manufacturing in view of its economic significance. A strong export-geared sector is good for innovation and therefore for solutions to societal problems. Manufacturing also helps create a lot of employment in other trades and industries: one job in manufacturing means 6-10 jobs elsewhere. Manufacturing is viable in Western economies because other location factors are becoming more important. These include knowledge, the clusters that are present, the convergence of research and production, and fiscal regulations, which are factors that can help Western economies compete. 
Market \& technology leaders like ASML, DAF, Philips and FEI in Brainport need high tech equipment in the semiconductor, medical, analytical, printing and photo voltaic sectors. Over 75 tier-one, tier-two and tier-three suppliers (SME's) in the open high-tech supply chain in the Netherlands have joined forces to create Brainport Industries. Brainport Industries designs develops and manufactures leading, advanced, precise and intelligent high-tech equipment. The Netherlands, and in particular the Brainport region around Eindhoven, are key players in the development, manufacturing and marketing of some of the most advanced, precise and intelligent machines. OEMs (Original Equipment Manufacturers) competing on the international market for high-mix, low-volume, high-complexity machines have been outsourcing the manufacturing of sub-assemblies and larger non-core submodules to strategic suppliers for quite some time and are now increasing the outsourcing of the design and development of the equipment they manufacture as well. What they're doing in fact is giving suppliers full responsibility for these modules, from design to manufacturing (www.brainportindustries.com).

This shift is driving suppliers to push their own boundaries in terms of feasibility and responsibility, and to extend their reach across international borders in order to tap into new, foreign markets. This can be quite challenging for individual suppliers because their companies are often too small or don't have enough financial power. But together, suppliers are strong. The leading tier-one, tier-two and tier-three hightech suppliers in the Netherlands (not only in the Brainport region) gave this unique high-tech hub a face: Brainport Industries. The cooperation was established so suppliers could join forces to strengthen the professional character and competitive position of the high-tech supply chain. As partners, suppliers can contribute to the continuity and growth of the high-tech industry. Brainport Industries provides a fertile ground and a solid structure for collaborative projects whether they are related to technology, markets or people. It's an environment that provides for a continuing flow of knowledge workers and experts and enables suppliers to increase their output and steadily grow into market leaders.

Companies and suppliers, united in the cooperation Brainport Industries design, develop and manufacture leading advanced, precise and intelligent high tech equipment. Brainport Industries is therefore the high-tech supply chain of choice for international OEMs competing on the international market for high-mix, lowvolume, high-complexity machines that want their concepts worked out into machines or submodules. The open supply chain is created through collaborative projects in Technology \& Process, Market \& Value chain, People \& Cooperation. Along with the OEM's (ASML, Philips, FEI etc.) these suppliers contribute to the growing international allure of Brainport, creating opportunities for the business communities in the region, both home-grown and foreign, who then locate to Brainport.

Brainport Industries is working with the Eindhoven council on plans to develop its own high-tech campus for suppliers working in the high tech sector. The Brainport Industries Park will be located to the west of the A2 near the Eindhoven 
Airport. This future campus will provide an environment where companies can freely collaborate with each other. The goal is to create a high-tech hub with a fertile environment that fosters creativity and positions this Dutch supplier chain on the international high-tech map. The atmosphere of this park will be collaborative, modern and green. With a campus of its own, the chain of companies (Brainport Industries) working in the high tech area will be able to carry out its projects and programmes and accommodate new types of collaboration. A so-called CFT 2.0's shared facilities centre, for example, will be located here to establish a link between education, research and practice. The campus and its companies will also attract highly qualified employees, knowledge and expertise, and drive entrepreneurship. The campus will also help create an appealing and healthy region: High Tech, High Green, High Culture.

\section{Brainport, Intelligent Community of the Year 2011}

In 2011 Brainport region Eindhoven was voted 'Intelligent Community of the Year 2011' by the Intelligent Community Forum, an award that acknowledges the region's strong international position. In international terms, the innovative performances of the Netherlands and Brainport region Eindhoven in 2011 remain comparable with those of the previous year. While its research system and intellectual performances are among the best in the world, the Netherlands lags behind in the number of innovative companies and amount of R\&D. But these are precisely the areas in which Brainport region Eindhoven excels and is regarded as one of Europe's most innovative regions, with good prospects of strengthening that position.

\section{Challenges for Brainport}

It is from this position of strength that the region faces up to major challenges. Various trend reports alert to trends such as demographic and climate change, technological innovations, scarcity and globalization. In terms of this last trend, the emerging economies of BRIC countries (Brazil, Russia, India and China), among others, have a sizeable impact.

The Dutch government has responded to these trends by introducing a new industry policy geared to nine top sectors for the Netherlands. One of them is the Dutch top sector High Tech Systems and Materials. This policy has been carefully reviewed in a number of studies and recommendations have been made for its effective implementation. From this it appears that foreign companies are attracted to regional industrial concentrations. The link to European policy is also crucial, including the societal focal areas, and the strong existence of companies in the top of the High Tech Systems \& Materials sector in Brainport region Eindhoven has a good basis to benefit from this European policy. 


\subsection{Challenges regarding employment}

The recent economic crisis has led to a larger group of protracted unemployed. Ageing and a population in decline are concerns for the region. Compared to a decade ago, there are fewer young people and a much greater proportion of older people in the population composition.

In many policy studies and research reports the battle for talent remains a hot issue. The demand for highly educated technical personnel continues to rise and talent recruitment increasingly goes abroad. This is the case for both companies and countries. Social capital is also a key factor for both industry and the economic performance of regions. The Netherlands and Brainport region Eindhoven both score reasonably well in this respect. That universities welcome international students is apparent from the balance of home-grown and foreign enrolments. Foreign students are keen to come to the Netherlands and stay on to work there. For the third year in a row the region has a positive migration figure, with the Asian share in the region growing particularly strongly.

(http://www.brainporttalentregion.com/ and http://www.brainport.nl/en?session=46qv5985noaobvknocs3vph113) .

\subsection{Challenges regarding public $R \& D$ investments}

Brainport region Eindhoven performs well when it comes to technology indicators. The Southeast Brabant region is the Dutch R\&D hotspot, where R\&D investment totals 390 million euros of public funds and a good 2.1 billion euros of private funds. Despite the rise in public spending, this is still a very unbalanced ratio according to comparable high achieving regions in Europe. It is only in private R\&D spending that the region squeezes into the top 15 . On the other hand, Brainport region Eindhoven has more registered patents than any other region in Europe.

The three universities in the Southeast Netherlands score high in terms of the number of publications and they share attributable to international cooperation, which is the highest of all. Four in every ten innovative companies in the region cooperate in innovation and the sharing of international partnerships is significantly higher than the national average. While sales of innovative products by companies in the region have fallen in recent years, this is still three times higher than the national average.

The strong international position is an important asset of the region. Various studies reveal that knowledge is acquiring an increasingly international dimension. More countries are undertaking more research with an increasing number of researchers collaborating internationally. The presence of a large scale research infrastructure is a vital anchor for both multidisciplinary research and the formation of networks, talent and economic spin-off. So, in this sense, the low public R\&D spending mentioned above could constitute a potential risk for the region if companies decide to re-allocate their $R \& D$ centres. 


\section{Brainport strategy in Europe - Top Economy, Smart Society}

The Southeast Netherlands has a very promising base but the world is changing rapidly. The major societal themes of our era also have considerable impact on the competitiveness of the region: scarcity of raw materials, ageing population, climate change, the growing need for energy and food, congested roads and strong international competition. The European Union wants to tackle these problems and opportunities at a European level through an all-embracing programme: Europe 2020.

Brainport 2020 is a governmental assignment comprising a vision and strategy along with a tangible implementation programme. The assignment reads: "Develop, parallel with the airport and seaport visions, a cohesive and comprehensive vision of Brainport. At the level of the Southeast Netherlands with Brainport as its pivot and with a focus on cross-border links to Flanders and Nordrhein-Westfalen."

The Dutch government wants to make the Dutch economy one of the world's top five economies and has therefore opted to focus on top sectors. High Tech Systems \& Materials, Chemical Engineering \& Chemistry and Agrofood are especially substantial contributors to the Dutch economy. These three sectors account for $68 \%$ of all private spending on research and development, and together make up for almost half of all Dutch exports, the engine of economic growth. World players, multinationals and small and medium sized enterprises with strong export positions in these sectors are located in Southeast Netherlands. Only if the knowledge economy of the Southeast Netherlands gets the opportunity to grow that can a top 5 spot can be achieved for the country. Compared to top regions around the world with a similar business and technology profile, a European top three spot and a world top ten ranking are feasible for the Southeast Netherlands. But to achieve this, specific actions and investments are necessary. These are outlined in Brainport 2020. Europe 2020 is a strategy that uses economic actors to tackle societal issues. The approach of Brainport 2020 and the European Union correspond to a great extent, and the Cabinet's policy fits in perfectly with this.

Some of the ambitions expressed in Brainport 2020, Top Economy, and Smart Society includes:

- in 2020 the Southeast Netherlands will be among the top three European top technology regions and in the top ten on a global scale;

- the economic growth in the Southeast Netherlands of around 3\% is double the country's average;

- the industry base in the Southeast Netherlands is taking advantage of opportunities for growth, with its annual share of gross national product rising from 40 to 136 billion euros;

- three world renown field labs that function as an incubator of innovative solutions for home care, mobility and sustainable buildings;

- the Southeast Netherlands will be aiming for near full employment. Every talent will be used because the job market needs them all, from skilled workers to highly educated knowledge workers. 


\section{Summary}

Brainport is a top technology region of (inter)national importance in the Netherlands. An open and innovative ecosystem with a long tradition of succesful innovations that continues to this day. The region has a long tradition of successful innovations. An open and innovative ecosystem, continued today. The major industries are High-Tech Systems \& Materials, Food, Automotive, Life Tec (medical technology) and Design. Around this flourishing top technology and knowledge industry a network of companies such as (business-to-business) service providers, builders and transporters is developing. This ecosystem will continue tomorrow and in the future with solutions like Smart supply, High tech tools, systems in a package, and automotive solutions made to fit.

In 2011 the region was announced as the smartest region in the world. Brainport aims to maintain this position and strengthen it so that Brainport becomes a top technology region of European and global status. The strongest asset of Brainport is its cooperation among industrial champions, market and technology leaders, which is supported by the government. In this manner, a winning team through cooperation with new governance as starting point, may be formed.

Main facts

- the Netherlands rank 7th in competitiveness and knowledge economy (World Economic Forum September, 2011);

- Brainport (http://www.brainport.nl) is among Europe's top 20 innovative regions;

- companies in Brainport invest 2.1 billion euros in research and innovation (numbers of 2008);

- Brainport accounted for $€ 28$ billion of the Dutch economy (in 2008);

- each year Brainport produces more than half the patents in the Netherlands;

- Brainport Eindhoven has been declared 'Intelligent Community of the Year 2011 ' by the ICF (Intelligent Community Forum).

What is unique about the Brainport governance model:

- it is a strong, open, and innovative eco-system;

- it covers value chains from knowledge to skills / know-how;

- it involves high density of top-technology companies and research institutes;

- it has a strong tradition in co-operation;

- it is open minded and characterized by comprehensive research, development, business and willingness to cooperate.

The main features of the unique ecosystem and Brainport 2020 programme, including cooperating organizations in Southeast of the Netherlands around Brainport are:

- world-class companies: Knowledge-intensive international companies in the Southeast Netherlands that are active in one of the top sectors (High Tech Systems \& Materials, Chemical Engineering \& Chemistry and Agrofood) spend 
3.3 billion euros each year on research and development (R\&D) and export products and services worth 80 billion euro;

- companies with unique market positions like ASML, Canon (Océ), DAF, DSM, FEI, NXP, Philips and VION, plus many smaller but equally excellent companies like Fuji, Annatech, Vanderlande Industries, Kverneland, Pamgene and CFS. The internationally competitive creative industry also plays a key role;

- an innovative SME sector: about $26 \%$ of all companies in the Southeast Netherlands are innovative). Moreover, the participation of small and mediumsized enterprises in national innovation schemes, innovation vouchers, innovation performance contracts and innovation programmes is above average: $44 \%$ of these specific national funds ends up in the Southeast Netherlands;

- strong supply chains: The Southeast Netherlands has powerfully embedded chains of suppliers of services (like R\&D) and semi-finished products in manufacturing. Research and development, design, production and sales all occur within close proximity of each other, with $70 \%$ of the first-line suppliers of several major OEMs (Original Equipment Manufacturers) located within $40 \mathrm{~km}$ of Eindhoven. The same applies to second and third-line ancillary suppliers which cooperate in the high tech open supply chain 'Brainport Industries';

- a well educated labour force with a qualitatively effective range of education and a knowledge infrastructure with close ties to the industry. At all educational levels (from secondary to university) educational establishments work with the industry. However, in a quantitative sense, compared with the national average, the public knowledge infrastructure is not up to par;

- open innovation: Companies cooperate with each other and with internationally active knowledge institutes like universities, university medical centres and hospitals TNO and the Dutch Polymer Institute cooperate by sharing and multiplying knowledge in an open environment before they introduce their products to the market. Open innovation is almost always multidisciplinary; bèta programmes work with market researchers, sociologists and psychologists. Meeting facilities and accessible research facilities are key factors;

- innovation campuses with international allure: High Tech Campus Eindhoven and Chemelot Campus in Sittard-Geleen are built on the strong foundations of the top players in High Tech Systems \& Materials, Chemical Engineering \& Chemistry, Philips and DSM. The campuses have unique research facilities and form hotspots for innovation. Their profile and power have been reinforced by the location of tens of companies that fit into the ecosystem;

- strategic location in Northwest Europe: The Southeast Netherlands is well positioned between the metropolitan areas of the Dutch Randstad, the German Ruhr and Flemish urban diamond with 55 million consumers within a range of 200 kilometres, and three intercontinental airports just $100 \mathrm{~km}$ away;

- powerful European player: The economy of the Southeast Netherlands acts on a European level in various partnerships and in the top technology region of Eindhoven-Leuven-Aachen; 
- triple helix cooperation: The Brainport Eindhoven region has a unique tradition of partnership between industry, knowledge institutions and government that drives the region forward. The cooperation between government, companies and knowledge institutes was created in the crisis period of the ' $90 \mathrm{~s}$ and is now embedded in the Brainport Development organization;

- pleasant place to live: The Southeast Netherlands offers a pleasant place to live with a combination of urban and rural living in a green, sustainable environment with an open, hospitable mentality, good sports facilities, and cultural amenities.

\section{References}

BRAINPORT DEVELOPMENT NV, (2011) Brainport2020, Top economy, Smart society, Eindhoven.

BRAINPORT DEVELOPMENT NV, (2012), Brainport Monitor, Eindhoven

ROMPA J. (2011), CLUSNET, Case Study, Eindhoven Seminar 2011, Brainport Development NV, Eindhoven, May, n. 10.

EUROSTAT, European statistics, 2003, 2005, 2007, 2009

WINTJES R. (2011), Regional Innovation Monitor, regional innovation report NorthBrabant, Technopolis Group, UNI-Merit, University of Maastricht, August, n. 24.

International publications in 2012 on Brainport, Smartest Region:

AKHTAR O. (2012), "The Best New Cities for Startups", Fortune, September, n. 9.

KACZMARSKI, M. (2012), "Collaboration proves key to Eindhoven's innovation and success", Financial Times, February, n. 10.

STABENOW M. (2012), "Wir sind die Schlaueste Region der Welt", Frankfurter Allgemeine Zeitung, October, n. 9. 